\title{
Deteksi Keberadaan Nyamuk berdasar atas Ketinggian Gedung di Kawasan Kampus Universitas Padjadjaran Jatinangor
}

\author{
Lia Faridah, ${ }^{1}$ Inggrid Leonita, ${ }^{2}$ Sri Yusnita Irda Sari ${ }^{3}$ \\ ${ }^{1}$ Departemen Mikrobiologi dan Parasitologi Fakultas Kedokteran Universitas Padjadjaran Bandung, Indonesia, \\ ${ }^{2}$ Fakultas Kedokteran Universitas Padjadjaran Bandung, Indonesia, ${ }^{3}$ Departemen Ilmu Kesehatan Masyarakat \\ Fakultas Kedokteran Universitas Padjadjaran Bandung, Indonesia
}

\begin{abstract}
Abstrak
Demam berdarah dengue (DBD) di Indonesia menurut data Kemenkes telah menjadi masalah kesehatan selama 45 tahun terakhir, sejak tahun 1968 sampai saat ini. Pada tahun 1973 dan 1983 progresivitasnya meningkat hingga lebih dari 50\% kabupaten/kota telah terjangkit kasus DBD. Kabupaten Sumedang sendiri memiliki insidensi 63,75 per 1.000 penduduk dengan jumlah kasus DBD sekitar 715 kasus pada tahun 2012. Tujuan penelitian ini adalah mengevaluasi persebaran nyamuk berdasarkan ketinggian gedung menggunakan media ovitrap dan mosquitoes light trap pada tujuh gedung bertingkat di kawasan kampus Universitas Padjadjaran Jatinangor yang memiliki ketinggian hingga level empat (9,1-12,0 m). Penelitian ini dilakukan pada bulan Mei-Juni 2017. Semua ovitrap diletakkan pada lokasi yang berpotensi sebagai breeding site di dalam ruangan selama satu minggu, tiaptiap lantai terdapat tiga ovitrap dengan jarak antar ovitrap 1,5 m. Perangkap nyamuk diletakkan pada setiap sudut ruangan yang memiliki sumber arus listrik selama 24 jam dan pengumpulan sampel dilakukan dalam kurun waktu tiga hari berikutnya. Semua sampel kemudian diidentifikasi di Laboratorium Parasitologi Fakultas Kedokteran Universitas Padjadjaran Jatinangor. Culex spp dan Aedes spp genus nyamuk yang dapat ditemukan pada gedung bertingkat di kawasan kampus Universitas Padjadjaran Jatinangor dengan jumlah terbanyak adalah Culex spp, sedangkan Aedes spp ditemukan dapat bertelur hingga tingkat tiga pada pemukiman yang padat.
\end{abstract}

Kata kunci: Gedung bertingkat, genus, light trap, nyamuk, ovitrap

\section{Detection of Mosquito Presence based on Building Elevation in Universitas Padjadjaran Jatinangor}

\begin{abstract}
According to the Ministry of Health (KMoH), Dengue Hemorrhagic Fever (DHF) has been a big problem in Indonesia since 1968. In 1973 and 1983, the progressivity of DHF has increased. DHF cases have spread to more than $50 \%$ of districts/cities. Sumedang District has an incidence rate of 63.75 per 1,000 residents with the number of dengue cases of 715 in 2012. The purpose of this study was to evaluate of the presence of mosquito based on building elevation using ovitraps and mosquito light traps. A survey was conducted in seven locations with four different elevations (9.1-12.0 m) in Universitas Padjadjaran Jatinangor campus during the period of May to June 2017. All ovitraps were each placed in a potential location for mosquito breeding site for one week. For each elevation, in this case, each floor, three ovitraps were placed with a distance $1.5 \mathrm{~m}$ from each other. Modified mosquito light trap was turned on for 24 hours and sample collection was performed after three days. All samples were brought to the Parasitology Laboratory of the Faculty of Medicine, Universitas Padjadjaran for identification. This study showed that two genera of mosquitoes were identified i.e. Culex spp and Aedes spp with Culex spp as the most frequently found genera. The eggs of Aedes spp can be found up to the third floor in dense settlements.
\end{abstract}

Key words: Genera, high level building, light trap, mosquito, ovitrap

Korespondensi: Lia Faridah, dr., M.Si, Departemen Mikrobiologi dan Parasitologi Fakultas Kedokteran Universitas Padjadjaran, Jalan Raya Bandung-Sumedang Km.21 Jatinangor, Sumedang, Jawa Barat, E-mail: lia.faridah@unpad.ac.id 


\section{Pendahuluan}

Nyamuk merupakan vektor penyebaran penyakit yang umum sangat dikenal. Menurut data World Health Organization nyamuk sebagai vektor beberapa penyakit infeksi dapat mengakibatkan jutaan kematian setiap tahun. Infeksi virus Zika, demam dengue, chikungunya, Rift Valley fever, dan yellow fever ditransmisikan oleh nyamuk Aedes aegypti. Malaria ditransmisikan oleh nyamuk Anopeles. Japanese encephalitis, lymphatic filariasis, West Nile fever ditransmisikan oleh nyamuk Culex. Pada tahun 2005 dilaporkan bahwa malaria menyebabkan 438.000 kematian. Insidensi infeksi virus demam berdarah dengue di dunia mengalami peningkatan 30 kali lipat

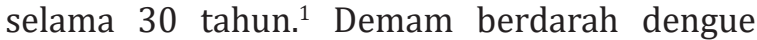
telah menjadi masalah kesehatan menurut data Kemenkes RI selama 45 tahun terakhir, sejak tahun 1968 sampai saat ini. Pada tahun 1973 dan 1983 progresivitasnya meningkat hingga lebih dari 50\% kabupaten/kota telah tersebar kasus DBD. ${ }^{2}$ Jawa Barat menempati posisi ketiga belas sebagai provinsi dengan IR (incidence rate) DBD di Indonesia pada periode 2016, yaitu mencapai 77,31 per 100.000 penduduk. ${ }^{1}$ Kabupaten Sumedang memiliki insidensi 63,75 per 1.000 penduduk dengan jumlah kasus DBD sekitar 715 kasus pada tahun $2012 .^{2}$

Kampus Universitas Padjadjaran terletak di Kecamatan Jatinangor, Kabupaten Sumedang, Jawa Barat. Kabupaten Sumedang terbagi dalam 26 kecamatan, 272 desa, serta 7 kelurahan. Salah satu kecamatan adalah Kecamatan Jatinangor yang merupakan daerah sentralisasi pendidikan, akibat kondisi tersebut jumlah penduduk yang masuk pada setiap tahunnya meningkat seiring dengan peningkatan jumlah mahasiswa baru yang mendaftar. Kecamatan Jatinangor memiliki luas area $2.620 \mathrm{Ha}$, dengan ketinggian rata-rata 501-1.000 meter dari permukaan laut, dan menjadi daerah aliran sungai Citarum (Dinas Pertanian Kabupaten Sumedang) ${ }^{3}$ sehingga memungkinkan menjadi habitat nyamuk dalam bertelur.

Nyamuk dewasa dapat terbang lebih dari 20 mil jauhnya dari sumber air tempat mereka berkembang. Namun, nyamuk tersebut tidak dapat terbang dengan cepat, kurang lebih hanya 4 mil per jam. Penyebaran dapat meluas secara pasif, misalnya terbawa angin atau kendaraan. ${ }^{4}$

Ovitrap sudah dirancang sebagai alat untuk dapat memantau populasi Aedes. Kegunaan dasarnya dalam memantau populasi Aedes telah direkomendasikan oleh WHO. Selain itu, banyak penelitian mengenai perolehan populasi nyamuk dari sampel menggunakan CDC light traps. ${ }^{6}$ Namun berdasarkan hasil penelitian Renate dkk. penggunaan light trap saja tidak cukup sehingga diberi atraktan lain berupa $\mathrm{CO}_{2}$ dari fermentasi ragi terhadap larutan gula. ${ }^{7}$ Telah banyak penelitian mengenai distribusi nyamuk di seluruh dunia, namun masih sedikit di Indonesia. Penelitian ini bertujuan mengevaluasi persebaran nyamuk berdasar atas ketinggian gedung menggunakan ovitrap dan mosquitoes light trap yang sudah dimodifikasi dengan penambahan atraktan.

\section{Metode}

Penelitian telah mendapat ijin dari Komisi Etik Penelitian Kedokteran FK Unpad dengan no. 427/UN6.C10/PN/2017. Lokasi sampling ini dilakukan di kawasan kampus Universitas Padjadjaran (Unpad) yang terletak di Kecamatan Jatinangor, Kabupaten Sumedang, Jawa Barat, dilaksanakan pada bulan Mei hingga Juni 2017. Lokasi penelitian dilakukan pada tujuh gedung bertingkat di kawasan kampus Universitas Padjadjaran Jatinangor dengan ketinggian hingga level empat $(9,1-12,0 \mathrm{~m})$. Rancangan penelitian yang digunakan adalah enthomology survey method. Sampel penelitian ini adalah nyamuk dan telur nyamuk yang terdapat di lokasi penelitian.

Ovitrap dibuat dengan menggunakan wadah bervolume $500 \mathrm{~mL}$ yang telah diwarnai hitam sebelumnya yang diberi larutan gula merah dan ragi. Semua ovitrap diletakkan pada lokasi yang berpotensi sebagai tempat berkembang biak di dalam ruangan selama satu minggu, tiap-tiap lantai dipasang tiga ovitrap dengan jarak antar-ovitrap 1,5 m. Perangkap nyamuk diletakkan pada setiap sudut ruangan yang memiliki sumber arus listrik selama 24 jam dan pengumpulan sampel dilakukan dalam kurun waktu tiga hari berikutnya. Semua sampel yang sudah didapatkan kemudian diidentifikasi di

\section{Tabel 1 Genus Nyamuk yang Terdapat di} Kampus Unpad Jatinangor

\begin{tabular}{lccc}
\hline \multicolumn{1}{c}{ Genera } & \multicolumn{1}{c}{ o } & $q$ & Total \\
\hline $\begin{array}{l}\text { Culex spp } \\
\text { Aedes spp }\end{array}$ & 24 & 22 & 46 \\
$\begin{array}{l}\text { Anopheles } \\
\text { spp }\end{array}$ & 0 & 2 & 3 \\
\hline
\end{tabular}

Keterangan: $\widehat{\jmath}$ : Laki-laki; 우 : Perempuan 
Lia Faridah dkk.: Deteksi Keberadaan Nyamuk berdasar atas Ketinggian Gedung di Kawasan Kampus Universitas Padjadjaran

Tabel 2 Jumlah Nyamuk per Lokasi Berdasar atas Spesifik Genus

\begin{tabular}{lccccc}
\hline & Perkantoran & $\begin{array}{c}\text { Gedung } \\
\text { Perkuliahan }\end{array}$ & $\begin{array}{c}\text { Tempat } \\
\text { Umum }\end{array}$ & Asrama & Total \\
\hline Culex spp & 1 & 4 & 6 & 35 & 46 \\
Aedes spp & 0 & 0 & 0 & 3 & 3 \\
Anopheles spp & 0 & 0 & 0 & 0 & 0 \\
\hline
\end{tabular}

Tabel 3 Jumlah Nyamuk bedasar atas Ketinggian Gedung

\begin{tabular}{|c|c|c|c|c|c|c|c|}
\hline \multirow{2}{*}{$\begin{array}{l}\text { Level Gedung } \\
\text { [Tinggi (m)] }\end{array}$} & \multicolumn{2}{|c|}{ Culex spp } & \multicolumn{2}{|c|}{ Aedes spp } & \multicolumn{2}{|c|}{ Anopheles spp } & \multirow[t]{2}{*}{ Total } \\
\hline & o & q & o & q & $0^{\lambda}$ & 우 & \\
\hline Level $1(\leq 3 \mathrm{~m})$ & 16 & 11 & 1 & 2 & 0 & 0 & 30 \\
\hline Level $2(3,1-6,0 \mathrm{~m})$ & 2 & 6 & 0 & 0 & 0 & 0 & 8 \\
\hline Level $3(6,1-9,0 \mathrm{~m})$ & 3 & 5 & 0 & 0 & 0 & 0 & 8 \\
\hline Level 4 (>9 m) & 3 & 0 & 0 & 0 & 0 & 0 & 3 \\
\hline
\end{tabular}

Keterangan: $\jmath^{\Uparrow}$ : Laki-laki; $\uparrow:$ Perempuan

Laboratorium Parasitologi Fakultas Kedokteran Universitas Padjadjaran Jatinangor.

\section{Hasil}

Hasil penelitian ini menunjukkan dua genus yang umum ditemukan pada gedung bertingkat di kawasan Kampus Universitas Padjadjaran adalah Aedes spp dan juga Culex spp., dengan jumlah terbanyak adalah Culex spp. Hasil lain menunjukkan bahwa baik telur Aedes maupun nyamuk dewasa dari genus Aedes dan Culex dapat ditemukan hingga level ketinggian 4, namun didapatkan penurunan jumlah seiring tingginya lantai gedung. Jumlah nyamuk terbanyak dapat ditemukan pada lantai satu. Sampel telur yang dikumpulkan pada ovitrap menunjukkan jumlah terbanyak terdapat pada lantai satu area asrama mahasiswa.

\section{Pembahasan}

Culex spp merupakan nyamuk terbanyak yang ditemukan di gedung bertingkat di kawasan Kampus Universitas Padjadjaran. Penelitian Dalhatu dkk ${ }^{8}$ di Nigeria, menunjukkan bahwa genus Culex spp. dapat ditemukan pada setiap ketinggian. Penelitian Gillies dan Wilkies ${ }^{4}$ di

Tabel 4 Jumlah Telur Nyamuk per Lokasi Berdasar atas Spesifik Genus

\begin{tabular}{lccccc}
\hline & Perkantoran & $\begin{array}{c}\text { Gedung } \\
\text { Perkuliahan }\end{array}$ & Tempat Umum & Asrama & Total \\
\hline Culex spp & 0 & 0 & 0 & 0 & 0 \\
Aedes spp & 0 & 0 & 0 & 93 & 93 \\
Anopheles spp & 0 & 0 & 0 & 0 & 0 \\
\hline
\end{tabular}

Tabel 5 Telur Nyamuk per Lokasi Berdasar atas Ketinggian Gedung

\begin{tabular}{lccccc}
\hline $\begin{array}{c}\text { Level Gedung } \\
\text { [Tinggi (m)] }\end{array}$ & Perkantoran & $\begin{array}{c}\text { Gedung } \\
\text { Perkuliahan }\end{array}$ & $\begin{array}{c}\text { Tempat } \\
\text { Umum }\end{array}$ & Asrama & Total \\
\hline Level 1 ( $\leq 3 \mathrm{~m})$ & 0 & 0 & 0 & 79 & 79 \\
Level 2 (3,1-6,0 m) & 0 & 0 & 0 & 0 & 0 \\
Level 3 (6.1-9,0 m) & 0 & 0 & 0 & 14 & 14 \\
Level 4 (>9 m) & 0 & 0 & 0 & 0 & 0 \\
\hline
\end{tabular}


Gambia menggunakan light traps menunjukkan penurunan jumlah nyamuk setiap kenaikan ketinggian.

Aedes spp ditemukan terbanyak di daerah asrama karena antargedung tersebut dibangun berdekatan serta letaknya yang cukup dekat dengan pemukiman warga membuatnya menjadi tempat yang baik untuk perkembangbiakan Aedes spp. ${ }^{9}$ Waktu mencari makanan (feeding time) nyamuk dipengaruhi oleh waktu terbit dan tenggelamnya matahari. ${ }^{10}$ Nyamuk yang aktif mencari makanan pada siang hari (diurnal) tidak merespons baik pada light traps dalam kasus ini adalah nyamuk Aedes spp dan mendukung oleh penelitian Thurman dan Thurman pada tahun 1955. Sekalipun light traps telah dimodifikasi dengan atraktan $\mathrm{CO}_{2}$ dari campuran air gula merah dan ragi, namun efektivitasnya tidak mampu menarik nyamuk diurnal dengan baik. ${ }^{11}$

Anopheles spp tidak ditemukan dalam penelitian kali ini, hal ini kemungkinan karena genus ini lebih banyak ditemukan pada malam hari pada saat manusia beristirahat malam. ${ }^{12}$ Pada penelitian yang dilakukan di Nusa Tenggara Barat dan Jawa Tengah menunjukkan hasil bahwa beberapa spesies Anopheles lebih banyak ditemukan di persawahan (An.annularis; An. subpictus; An. vagus), di daerah dataran tinggi (An.barbirostris), ${ }^{13}$ dan dari spesies tersebut lebih bersifat zoophilic yang menghisap darah hewan sehingga ditemukan di area peternakan (An. subpictus; An. vagus) dibanding dengan area perumahan. ${ }^{14}$

Telur Aedes spp. yang dikumpulkan dengan ovitrap menunjukkan bahwa paling banyak ditemukan di lantai satu dengan ketinggian berkisar 0,0-3,0 meter, keadaan ini mendukung penelitian Chadee dkk. ${ }^{9}$ bahwa Aedes spp. melakukan oviposition (peletakan telur) pada ketinggian 1,2 meter dan hanya sedikit pada ketinggian 4,6 meter. Namun, berdasarkan hasil penelitian Romero Vivas dkk. Pada tahun 2007 hasil ovitrap tidak dapat memperkirakan secara akurat populasi Aedes spp. dewasa. ${ }^{15}$ Telur Culex spp tidak ditemukan pada penelitian kali ini dikarenakan Culex spp biasa meletakkan telurnya pada air tenang yang mengandung kandungan unsur organik tinggi untuk perkembangan larva Culex spp. ${ }^{6}$ Selain itu, pada penelitian ini, nyamuk Anopheles spp tidak ditemukan sehingga telur nyamuk Anopheles spp pun tidak dapat kami ditemukan.

Keberadaan suatu nyamuk di suatu daerah itu bergantung pada faktor-faktor tertentu. Secara ekologis keberadaan ekosistem biotik (manusia, tumbuhan, hewan) serta abiotik (struktur, temperature, kelembaban dan angin) membentuk komponen yang memberikan asupan makanan (darah manusia maupun hewan), air bagi tempat perkembangbiakan, serta habitat bagi nyamuk untuk beristirahat atau bersembunyi tidak hanya dapat ditemukan pada level ketinggian tanah atau pada lantai satu, namun pada semua tingkatan level gedung. ${ }^{9}$ Aktivitas manusia dan jumlah populasi manusia juga memengaruhi jumlah populasi nyamuk. ${ }^{16}$ Universitas Padjadjaran merupakan kawasan bagi mahasiswa untuk belajar dengan peningkatan jumlah setiap tahunnya karena jumlah mahasiswa baru yang mendaftar setiap tahunnya mengalami peningkatan serta lokalisasi pendidikan yang berpusat di daerah Jatinangor, Sumedang, Jawa Barat.

Dalam penelitian ini jumlah nyamuk yang didapatkan juga dipengaruhi oleh banyaknya bangunan baru yang menjadi lokasi penelitian. Bangunan baru oleh karena masih mempunyai keadaan yang bersih sehingga habitat nyamuk untuk bersembunyi masih sedikit. Selain hal tersebut, bangunan baru ini masih belum lama difungsikan dan aktivitas manusia di gedung ini masih sedikit.

Secara umum, hasil penelitian ini sudah menunjukkan bahwa keberadaan nyamuk di dalam ruangan (indoor) dapat ditemukan hingga tingkat empat dan nyamuk Aedes spp dapat bertelur hingga tingkat tiga sehingga perlukan kesadaran mahasiswa untuk mengeliminasi breeding habitat yang ada di dalam gedung dengan menjaga kebersihan. Komponen utama dalam strategi pengontrolan vektor adalah modifikasi lingkungan terutama penampungan air untuk memutus siklus hidup vektor. ${ }^{6}$ Semua penampungan air harus dibersihkan secara rutin, bila perlu pemberian larvasida secara berkala untuk penampungan air yang susah dibersihkan. ${ }^{17}$

Simpulan, Culex spp dan Aedes spp adalah genus nyamuk yang dapat ditemukan di gedung bertingkat di kawasan kampus Unpad Jatinangor dengan jumlah terbanyak adalah Culex spp. Aedes spp dapat bertelur hingga tingkat tiga pada pemukiman yang padat, yaitu di area asrama mahasiswa.

\section{Ucapan Terima Kasih}

Ucapan terima kasih dan apresiasi kepada para pengajar, Laboratorium Parasitologi di Fakultas Kedokteran Universitas Padjadjaran serta rekan-rekan yang ikut membantu dan memberi 
dukungan selama penelitian ini. Penelitian ini didukung oleh Hibah Kementerian Riset Teknologi dan Pendidikan Tinggi Republik Indonesia.

\section{Daftar Pustaka}

1. Amrul Munif. Nyamuk vektor malaria dan hubungannya dengan aktivitas kehidupan manusia di Indonesia. Aspirator. 2009;1(2): 94-102.

2. Departemen Kesehatan Jawa Barat. Profil Kesehatan Provinsi Jawa Barat Tahun 2012. Bandung: Depkes Jawa Barat; 2012.

3. BPS. Kabupaten Sumedang dalam angka Tahun 2010. Badan Pusat Statistik Kabupaten Sumedang; 2010.

4. Makkatenni, Atjo N, Juhardi, JaliL. Analisis terhadap densitas larva nyamuk Aedes aegypti di Kecamatan Bungoro Kabupaten Pangkep. Prosiding Seminar Nasional from Basic Science to Comprehensive Education. 26 Agustus 2016; Makassar. Makassar: UIN Alauddin Makassar; 2016.

5. WHO. Vector control in International Health. Geneva: World Health Organization; 1972.

6. Sriwichai P, Karl S, Samung Y, Sumruayphol S, Kiattibutr K, Payakkapol A. Evaluation of CDC light traps for mosquito surveillance in a malaria endemic area on the Thai-Myanmar border. Parasites Vectors. 2015;8:636.

7. Smallegange RC, Schmied WH, van Roey KJ, Verhulst NO, Spitzen J, Mukabana WR, dkk. Sugar-fermenting yeast as an organic source of carbon dioxide to attract the malaria mosquito Anopheles gambiae. Malaria J. 2010;9:292.

8. Dalhatu A, Omar AA, Bagari H. Surveillance of mosquito species abundance and composition in Azare, Katagum local government of Bauchi State, Nigeria. IOSR J Pharm Biol Sci. 2016;11(6):105-9.
9. Eisen L, Monaghan AJ, Lozano-Fuentes S, Steinhoff DF, Hayden MH, Bieringer PE. The impact of temperature on the bionomics of Aedes (Stegomyia) aegypti, with special reference to the cool geographic range margins. J Med Entomol. 2014;51(3):49616.

10. Fahmi M. Studi keanekaragaman spesies nyamuk Anopheles sp. di Kabupaten Donggala Provinsi Sulawesi Tengah. Journal of Natural Science. 2014;3(2):96-7.

11. Hoel ADF, Kline DL, Allan SA. Evaluation of six mosquito traps for collection of Aedes albopictus and associated mosquito species in a suburban setting in North Central Florida. J Am Mosq Control Assoc. 2009;25(1):47-57.

12. Maria NI, Audrey LEJ. Mosquito borne diseases in Ambon municipality. Occasional Papers. 2014;2(54):67-74.

13. Ndoen E, Wild C, Dale P, Sipe N, Dale M. Relationships between anopheline mosquitoes and topography in West Timor and Java, Indonesia. Malaria J. 2010;9(1):242.

14. Elyazar IR, Sinka ME, Gething PW, Tarmidzi SN, Surya A, Kusriastuti R, dkk. The distribution and bionomics of Anopheles malaria vector mosquitoes in Indonesia. Adv Parasitol. 2013;83(3):173-209.

15. Wan-Norafikah O, Nazni WA, Noramiza S, Shafa'ar-Ko'ohar S, Azirol-Hisham A, NorHafizah R, dkk. Vertical dispersal of Aedes (Stegomyia) spp in high-rise apartments in Putrajaya, Malaysia. Trop Biomed. 2010;27(3):662-7.

16. Rozilawati H, Zairi J, Adanan CR. Seasonal abundace of Aedes Albopictus in seclected urban and suburban areas in Penang, Malaysia. Trop Biomed. 2007;24(1):83-94.

17. Pratamawati DA. Peran juru pantau jentik dalam sistem kewaspadaan dini demam berdarah dengu di Indonesia. Jurnal Kesehatan Masyarakat. 2012;6(6):243-8. 